\title{
Analysis of Saline Intrusion into a Coastal Aquifer: A Case History of Legacy Issues and Challenges to Water Security
}

\author{
Nara Somaratne ${ }^{1} \&$ Glyn Ashman ${ }^{1}$ \\ ${ }^{1}$ South Australian Water Corporation, 250 Victoria Square, Adelaide, SA 5000, Australia \\ Correspondence: Nara Somaratne, South Australian Water Corporation, 250 Victoria Square, Adelaide, SA 5000, \\ Australia. Tel: 618-7424-2379. E-mail: nara.somaratnef@sawater.com.au
}

Received: March 8, 2018

Accepted: April 4, 2018

Online Published: April 9, 2018

doi:10.5539/enrr.v8n2p16

URL: https://doi.org/10.5539/enrr.v8n2p16

\begin{abstract}
Coastal aquifers are subject to seawater intrusion. Therefore, managing freshwater aquifers in coastal areas remain challenging. At present, determining safe yields from the coastal aquifers to prevent seawater intrusion is primarily based on the use of numerical simulation-optimization models or by the use of analytical models based on the Ghyben-Herzberg principle. This study examines the cause and effects of seawater intrusion into a coastal aquifer, Lincoln Basin in southern Eyre Peninsula, South Australia and shows that application of simple techniques would have prevented seawater intrusion. Three freshwater lenses, Lincoln A, B, and C of the Lincoln Basin, located about $13 \mathrm{~km}$ southwest of Port Lincoln township, have been developed as a town water supply source in 1960. The capacity of the basin has been assessed by three long-term pumping tests. Based on pump tests results, three areas were developed to supply $2 \times 10^{6} \mathrm{~m}^{3}$ per year distributed across three lenses as lens A : four wells to supply $0.84 \times 10^{6} \mathrm{~m}^{3}$, lens B: four wells to supply $0.5 \times 10^{6} \mathrm{~m}^{3}$ and lens C: four wells to supply $0.66 \times 10^{6} \mathrm{~m}^{3}$. Neither recharge to the freshwater lenses nor a water balance had been assessed, and a precautionary approach to groundwater extraction was not followed. The apparent driver for managing the basin was demand for the township. In this study, we assessed the recharge using two methods; water-table fluctuation (WTF) and the conventional chloride mass balance (CMB) method. Total recharge to the freshwater lenses is estimated at $1.6 \times 10^{6} \mathrm{~m}^{3}$ per year which is less than the average annual groundwater extraction from the basin during the 1961-1977 periods (average $2.14 \times 10^{6} \mathrm{~m}^{3}$ ). As a result mining of the groundwater storage has occurred in the basin leading to saline intrusion, upconing and lateral flow of brackish water into wellfield areas. The total volume extracted from the basin was $35 \times 10^{6} \mathrm{~m}^{3}$, which exceeded the average recharge over the 15 year period, $24 \times 10^{6} \mathrm{~m}^{3}$. Using analytical methods, the seawater/freshwater interface movement from its original position was estimated to be $35 \mathrm{~m}$ in lens A, $337 \mathrm{~m}$ in lens B and $188 \mathrm{~m}$ in lens C. For each pumping well at maximum discharge rate, the transient interface location directly underneath the well was calculated. This results in interface rises under pumping wells in lens A of $3.8 \mathrm{~m}$, lens B of $0.5 \mathrm{~m}$, and in lens C about $0.7 \mathrm{~m}$. According to the risk-based groundwater allocation method, maximum extraction would have been as a proportion of $25 \%$ of the annual recharge. Thus, maximum annual abstraction limits for lens $\mathrm{A}, \mathrm{B}$ and $\mathrm{C}$ would have been $210 \times 10^{3} \mathrm{~m}^{3}$, $72 \times 10^{3} \mathrm{~m}^{3}$ and $130 \times 10^{3} \mathrm{~m}^{3}$, totaling $412 \times 10^{3} \mathrm{~m}^{3}$.
\end{abstract}

Keywords: coastal aquifers, safe yield, saline intrusion, upconing, recharge, pumping, groundwater allocation

\section{Introduction}

In response to the rapid increase of water demand for the town of Port Lincoln, South Australia from $0.42 \times 10^{6}$ $\mathrm{m}^{3}$ in 1949-50 to approximately $1.135 \times 10^{6} \mathrm{~m}^{3}$ in 1959-60, a coastal aquifer, Lincoln Basin was developed as an additional source of water supply. The water supply scheme was designed with the expectation that three freshwater lenses in the Lincoln Basin would provide about $1.1 \times 10^{6} \mathrm{~m}^{3}$ per year. Notwithstanding that Lincoln Basin is surrounded by sea, and the watertable is just above the sea level, it was considered that the development of the basin was the best option meeting the need for augmentation (Shepherd, 1959, 1962). A consequence of this demand driven groundwater development was the increase in salinity of the basin. As a result, in 1976 an alternative groundwater basin was developed to supplement the demand, and consequently, the use of Lincoln Basin was drastically reduced.

Coastal groundwater is susceptible to degradation by sea water intrusion (Custodio, 1987a; Dagan \& Fares, 2008) and is a world-wide concern. In general, landward penetration of the salt water wedge increases with increasing 
aquifer thickness, hydraulic conductivity and with decreasing fresh water flow to the sea. Depending on the aquifer dispersivity, and the fresh water flow; a mixing zone develops between fresh and salt groundwater (Custodio, 1987b). When the mixing zone is thin relative to the aquifer thickness, it can be considered as a sharp interface between the fresh and salt water (Custodio, 1987b).

Seawater intrusion assessments have been made using a variety of methods and techniques including; direct monitoring (Tremblay et al., 1973), hydrochemical characterization (Kim et al., 2003; Carol et al., 2009), electromagnetic techniques (Goldman et al., 1991; Kafri \& Goldman, 2005), analytical modelling (Strack, 1976; Kacimov \& Obsonov, 2000; Kacimov et al., 2005, 2006) and numerical modelling (Huyarkon et al., 1987; Bobba, 2002). With regard to numerical modelling, Beebe et al. (2016) caution that the simulation of variable-density groundwater flow and solute transport in transient and heterogeneous coastal groundwater systems is computationally expensive, requires extensive field data for calibration, and is not always successful (Sanford \& Pope, 2010; Koussis et al., 2015). Because of its simplicity, the analytical solution (Strack, 1976) is widely used in lieu of sophisticated numerical modelling as a first order analysis of saline intrusion problems for data limited aquifers. There are a number of analytical models available for addressing seawater intrusion problems but the use of Strack (1976) sharp interface assumption and in particular, analytical solution are widely reported (Aharmouch \& Larabi, 2001; Montoglou, 2003; Morgan et al., 2013; Felisa et al., 2013; Naderi et al., 2013; Beebe et al., 2016). Since the sharp interface assumption neglects mixing, Pool \& Carrera (2011) extended the analytical solution to the case of mixing zones by modifying the density factor by an empirically derived dispersion factor. Citing Gingerich and Voss (2002), Pool and Carrera (2011) stated that the Ghyben-Herzberg depth is not a good predictor of the depth of potable water. This is because of its failure to deal effectively with the dynamic response of the mixing zone to changes in pumping or rapid recharge. The freshwater-seawater interface in the boreholes may not represent the interface in the aquifer because the borehole serves as a means of transferring vertical flow (Pool \& Carrera, 2011). Other factors such as heterogeneity in the hydraulic conductivity field, which leads to non-uniform advection, may contribute to enhance mixing. Heterogeneity also produces a seaward movement of the toe location along with a widening of the mixing zone. The width of the mixing zone is also influenced by the effects of tidal fluctuations (Pool \& Carrera, 2011).

In this paper, the authors present a case history of extraction beyond the aquifer capacity (Alley \& Leake, 2004; Kalf \& Wooley, 2005) and consequence salinization. We specifically provide answers to the following questions: what is the annual recharge to the aquifer compared with annual groundwater extractions; what is the position of the toe of the saline wedge under pre-development and post-development conditions, what is the extent of upconing under the maximum pumping rate of a production wells, what are the dominant mechanisms of saline water intrusion. In addition we estimate what would have been the extraction rate from the basin and, are there any available management options for security of water supply.

\section{Study site: Lincoln Basin, Southern Eyre Peninsula}

Three freshwater lenses, Lincoln A, B, and C of Lincoln Basin (Figure 1), located about $13 \mathrm{~km}$ southwest of Port Lincoln township, were developed as a town water supply source in 1960. The basin boundaries were defined by 186 exploratory wells drilled during the 1956-59 period and cover an area of approximately $155 \mathrm{~km}^{2}$. Recharge to the lenses is via direct rainfall infiltration. The principal direction of groundwater flows are eastern parts of the Lincoln A discharge easterly towards Port Lincoln Proper Bay and the southern part to the Sleaford Mere. The Sleaford Mere is a discharge area and considered to be part of the exposed water table. The water of Sleaford Mere has a salinity of $7000-11400 \mathrm{mg} \cdot \mathrm{L}^{-1}$, caused by evaporation. Groundwater flow within Lincoln B is northerly-northeasterly towards Port Lincoln Proper Bay and also towards Sleaford Mere (south-westerly). Groundwater flow within Lincoln C is predominantly north-westerly towards Port Lincoln Proper Bay.

The physiography and geology of the Lincoln Basin are given by Shepherd (1959), and a succinct summary is provided here. The northern part of the basin occupies a long relatively narrow depressed area between the high ground to the west. Surface runoff in the basin area is very limited, although occasional heavy storms cause some of the depressions to become partially flooded for short periods, as the soil is previous in the basin area (Shepherd, 1959). The bedrock of Archaean age underlies the Lincoln basin, in places at considerable depth and outcrops along the coast beyond the limit of the basin. Throughout the basin area, there is a considerable thickness, up to $150 \mathrm{~m}$ in places, of calcareous sandstone and limestone of Pleistocene-Recent age with possible upper Tertiary sediments (Shepherd, 1959). The deposits generally consist of wind blown medium-grained sand, often cemented by calcium carbonate to form aeolianite. Limestone occurs at various levels representing former surfaces during the process of formation of the dunes systems. Shepherd (1959) further described that very little clay occurs in the basin, except in the vicinity of shallow bedrock from which it has been derived by weathering and erosion. Occasional thin beds of unconsolidated sand appear in areas where the aeolianite has been eroded. 


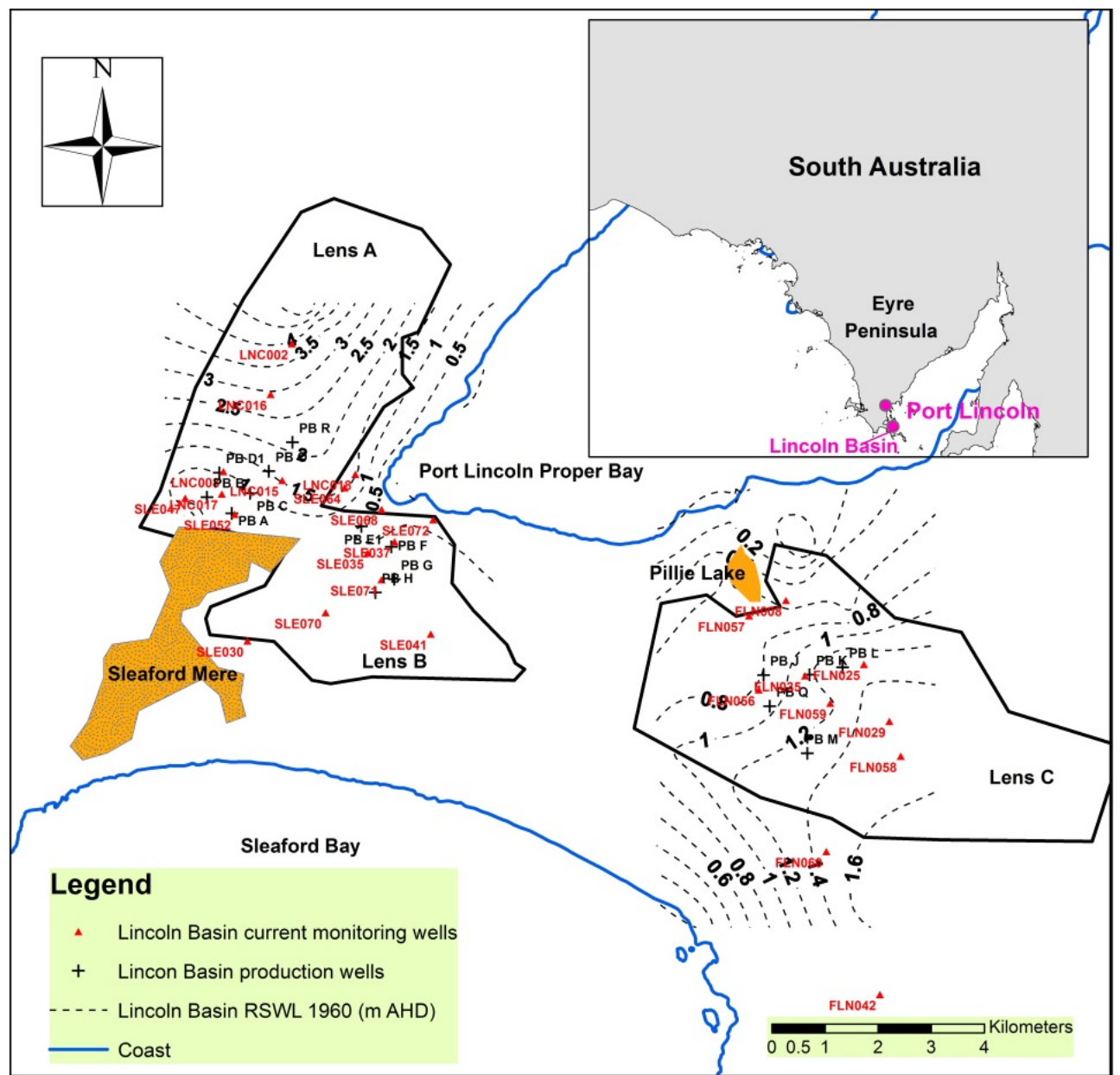

Figure 1. Lincoln Basin in the southern Eyre Peninsula

Freshwater lenses in the unconfined Quaternary Limestone (QL) aquifer occur with generally high yields and low salinity. This aquifer consists of fine shell fragments, which in some areas has developed solution features as well as secondary cementation. Pumping tests conducted in lens A show a widely varying hydraulic conductivity range of 192-1203 m.d. ${ }^{-1}$ (Sibanaler, 1975), in lens B, a single pumping test conducted in production well P (PB P) show hydraulic conductivity of $122 \mathrm{~m} . \mathrm{d}^{-1}$ and in lens $\mathrm{C}$, hydraulic conductivity range from $16.5 \mathrm{~m} . \mathrm{d}^{-1}$ to 220 $m . d^{-1}$. This aquifer has been primarily developed for reticulated public water supply.

\section{Methods}

\subsection{Theoretical Framework of Analyses: Strack (1976) Single Potential Solution}

In this study, an analytical solution developed by Strack (1976) for interface problems in coastal aquifers was used for analysis of the position of the saline water wedge. A single governing potential equation has been used by Strack (1976) to solve the problem across two zones of the coastal aquifer (Figure 2). The method simplifies the aquifer and flow system by assuming steady-state flow in a homogeneous aquifer where the vertical flow rates can be neglected in relation to horizontal ones (Dupuit-Forchheimer assumption). The interface separates the freshwater from saltwater at rest, then a single-valued and continuous potential can be defined; saltwater and freshwater are separated by an interface rather than by a transition zone; and flow rates in the saltwater region are negligible in relation to the flow rates in the freshwater region. Despite simplifying assumptions, analytical solutions can be used as a tool for first-order analysis prior to application of more sophisticated models (Cheng \& Ouazar, 1999). Potential flow theory of Strack (1976) is applied with several assumptions: the sea water-fresh water interface is a sharp interface instead of a variable density transition zone; the sea level is constant; the Dupuit-Forchheimer assumption is applied to neglect the vertical flow, and the Ghyben Herzberg formula is applicable. Saline wedge penetration into the aquifer depends on: aquifer hydraulic conductivity; the square of the aquifer thickness, and inversely on the freshwater flow to the sea (Custodio, 1987b). 


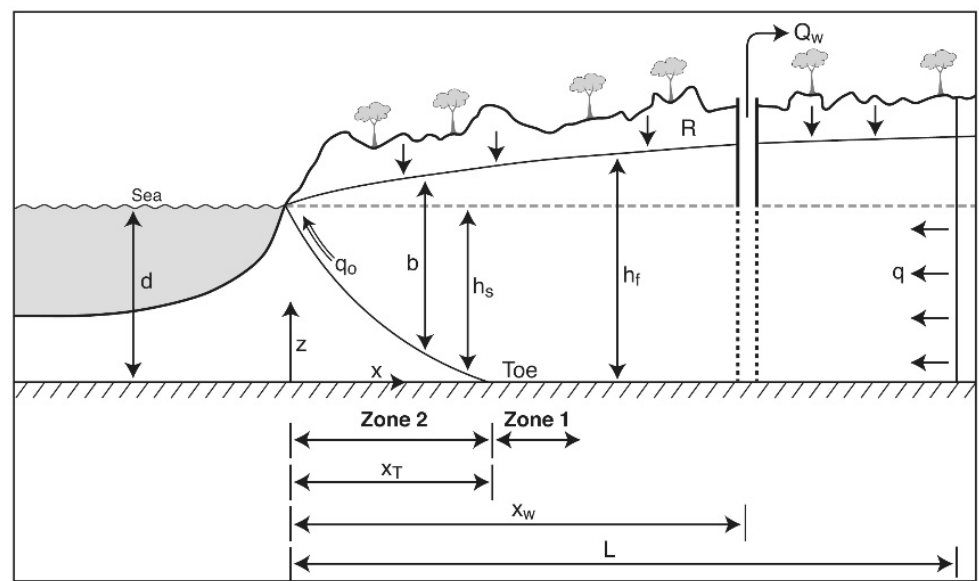

Figure 2. Interface flow in an unconfined aquifer with a pumping well

This approximation is more appropriate when flow conditions approach steady state. For an unconfined aquifer, the thickness of the freshwater layer is given by (Cheng \& Ouoazar, 1999):

It is possible then to use the Ghyben-Herzberg relation for Zone 2:
:

$$
\mathrm{b}=\mathrm{h}_{\mathrm{f}} \text { for Zone } 1 \text {; and } \mathrm{b}=\mathrm{h}_{\mathrm{f}}-\mathrm{d}+\mathrm{h}_{\mathrm{s}} \text { for Zone } 2
$$

$$
\mathrm{h}_{\mathrm{f}}-\mathrm{d}=\delta \mathrm{h}_{\mathrm{s}}
$$

$\delta=\left(\rho_{\mathrm{s}}-\rho_{\mathrm{f}}\right) / \rho_{\mathrm{f}} \approx 0.025$, for the density of seawater $\rho_{\mathrm{s}}\left(1025 \mathrm{mg} . \mathrm{L}^{-1}\right)$ and density of fresh water $\left(\rho_{\mathrm{f}}\right) 1000$ mg.L-1.

Following Strack (1976), the potential functions for Zone 1 and Zone 2 are defined for the unconfined aquifer:

$$
\begin{array}{cc}
\text { Zone } 1 & \varnothing=\frac{1}{2}\left[\mathrm{~h}_{\mathrm{f}}^{2}-(1+\delta) \mathrm{d}^{2}\right] \\
\text { Zone } 2 & \varnothing=\frac{(1+\delta)}{2 \delta}\left(\mathrm{h}_{\mathrm{f}}-\mathrm{d}\right)^{2}
\end{array}
$$

These functions and their first derivatives are continuous across the multiple zones of the aquifer and satisfy the Laplace equation, $\nabla^{2}=0$, in the $\mathrm{x}-\mathrm{y}$ plane (Felisa et al., 2013). The location of the toe is determined, when $\mathrm{h}_{\mathrm{s}}=\mathrm{d}$ and from equation (2); $\mathrm{h}_{\mathrm{f}}=(1+\delta) \mathrm{d}$ and substituting into equations. (3) or (4), flow potential at the toe is given by Mantoglou (2003):

$$
\emptyset_{\mathrm{T}}=\frac{(1+\delta) \delta}{2} \mathrm{~d}^{2}
$$

For a vertical cross-section of an unconfined aquifer with recharge $\mathrm{R}$, the governing equation is (Cheng \& Ouazar, 1999):

$$
\frac{\mathrm{d}^{2} \emptyset}{\mathrm{dx}^{2}}=-\frac{\mathrm{R}}{\mathrm{K}}
$$

Boundary conditions are:

$$
\phi=0 \text { at } \mathrm{x}=0 \text {, and } \frac{\mathrm{d} \phi}{\mathrm{dx}}=\frac{\mathrm{q}}{\mathrm{K}} \text { at } \mathrm{x}=\mathrm{L}
$$

where $\mathrm{q}$ is the freshwater volume outflow rate per unit length of coastline and $\mathrm{L}$ is the domain length. The solution of above is (Cheng \& Ouazar, 1999):

$$
\varnothing=\frac{\mathrm{R}}{2 \mathrm{~K}} \mathrm{x}^{2}+\left(\frac{\mathrm{q}}{\mathrm{K}}+\frac{\mathrm{RL}}{\mathrm{K}}\right) \mathrm{x}
$$

By substituting the potential value defined in equation (5) into equation (8), the location of the toe can be solved (Cheng \& Ouazar, 1999; Chang et al., 2011):

$$
x_{T}=\frac{q}{R}+L-\sqrt{\left(\frac{q}{R}+L\right)^{2}-\frac{K}{R} \delta(1+\delta) d^{2}}
$$

For simplicity, the effect of pumping on the position of the toe can be accounted for by replacing $\mathrm{R}$ with net recharge $\left(R_{n}\right)$ in equation (9) accounting for distributed pumping over the recharge area. Strack (1976) developed equations for $\mathrm{h}_{\mathrm{f}}$ as a function of aquifer parameters and distance from the coast, $\mathrm{x}$, For Zone $1\left(\mathrm{x} \geq \mathrm{x}_{\mathrm{T}}\right)$ : 


$$
\mathrm{h}_{\mathrm{f}}=\sqrt{\frac{2 \mathrm{q}_{0} \mathrm{x}-\mathrm{Rx}^{2}}{\mathrm{~K}}+(1+\delta) d^{2}}-\mathrm{d}
$$

For Zone $2\left(\mathrm{x} \leq \mathrm{x}_{\mathrm{T}}\right)$ :

$$
h_{f}=\sqrt{\frac{2 q_{0} x-R x^{2}}{K}\left(\frac{\delta}{(1+\delta)}\right)}
$$

Rearranging equations (10) and (11) yields:

For Zone 1:

$$
\mathrm{q}_{0}=\frac{\mathrm{K}\left(\left(\mathrm{h}_{\mathrm{b}}+\mathrm{d}\right)^{2}-(1+\delta) \mathrm{d}^{2}\right)+\mathrm{R} \mathrm{x}_{\mathrm{b}}^{2}}{2 \mathrm{x}_{\mathrm{b}}}
$$

For Zone 2:

$$
\mathrm{q}_{0}=\left(\frac{1+\delta}{\delta}\right)\left(\frac{\mathrm{K}}{2 \mathrm{x}_{\mathrm{b}}}\right) \mathrm{h}_{\mathrm{b}}^{2}+\frac{\mathrm{Rx}_{\mathrm{b}}}{2}
$$

where $h_{b}$ is the measured head at distance $x_{b}$ from the coast.

Now consider the case with the presence of a pumping /recharging well with discharge $\mathrm{Q}_{\mathrm{w}}$, located at a distance $\mathrm{X}_{\mathrm{W}}$ from the coast (Figure 2). The solution of the problem, in terms of potential, can be found by resorting to the superposition principle and the method of images as Strack (1976):

$$
\varnothing=\frac{\mathrm{q}}{\mathrm{K}} \mathrm{x}+\frac{\mathrm{Q}_{\mathrm{w}}}{4 \pi \mathrm{K}} \ln \left[\frac{\left(\mathrm{x}-\mathrm{x}_{\mathrm{W}}\right)^{2}+\left(\mathrm{y}-\mathrm{y}_{\mathrm{w}}\right)^{2}}{\left(\mathrm{x}+\mathrm{x}_{\mathrm{w}}\right)^{2}+\left(\mathrm{y}-\mathrm{y}_{\mathrm{w}}\right)^{2}}\right]
$$

The location of the toe of the saltwater wedge can be computed for the x-y plane from equations (5) and (14) as (Felisa et al., 2013; Naderi et al., 2013) for multiple wells:

$$
\phi_{\mathrm{T}}=\frac{\mathrm{q}}{\mathrm{K}} \mathrm{x}_{\mathrm{T}}+\sum_{\mathrm{i}=1}^{\mathrm{n}} \frac{\mathrm{Q}_{\mathrm{wi}}}{4 \pi \mathrm{K}} \ln \left[\frac{\left(\mathrm{x}_{\mathrm{T}}-\mathrm{x}_{\mathrm{wi}}\right)^{2}+\left(\mathrm{y}_{\mathrm{T}}-\mathrm{y}_{\mathrm{wi}}\right)^{2}}{\left(\mathrm{x}_{\mathrm{T}}+\mathrm{x}_{\mathrm{wi}}\right)^{2}+\left(\mathrm{y}_{\mathrm{T}}-\mathrm{y}_{\mathrm{wi}}\right)^{2}}\right]
$$

where ' $\mathrm{Q}_{\mathrm{wi}}$ ' is the pumping rate of $\mathrm{i}^{\text {th }}$ well located at coordinates $\left(\mathrm{x}_{\mathrm{wi}}, \mathrm{y}_{\mathrm{wi}}\right)$, and ' $\mathrm{n}$ ' is the number of wells. The Equations (14) and (15) are strictly valid for semi-infinite aquifer dimensions with a single boundary at the coastline (Montoglou, 2003).

For the examination of saltwater upconing, Cheng \& Ouazar (1999) presented a simple formula developed by Dagan \& Bear (1968).

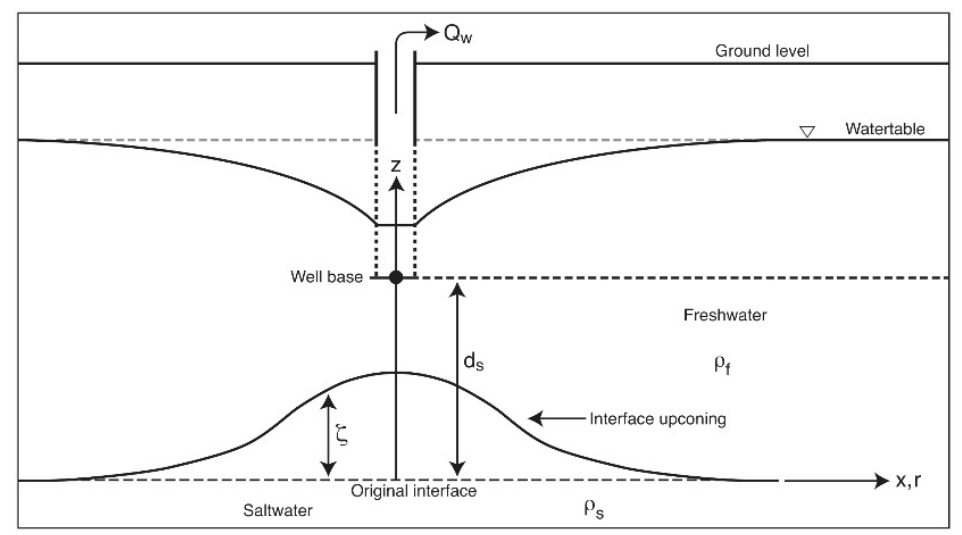

Figure 3. Upconing of the saltwater interface

For a well pumping at discharge $\mathrm{Q}_{\mathrm{w}}$, the transient interface location $(\zeta)$ directly underneath the well is given as (Cheng \& Ouazar, 1999):

$$
\zeta=\frac{Q_{w}}{2 \pi \delta \mathrm{Kd}_{\mathrm{s}}}
$$

For the saline wedge not to reach the well bottom, the maximum rise, $\zeta_{\max }$ must be less than depth to salt water $\left(d_{s}\right)$. Hence maximum pumping rates is: 


$$
\mathrm{Q}_{\max }<\frac{2 \pi \mathrm{Kd}_{\mathrm{s}}^{2}}{\delta}
$$

For safety considerations, $\zeta_{\max }=0.3 \mathrm{~d}_{\mathrm{s}}$ (Cheng \& Ouazar, 1999), therefore the following equation is often used to calculate the critical pumping rate:

$$
\mathrm{Q}_{\max }<\frac{0.6 \pi \mathrm{Kd}_{\mathrm{s}}^{2}}{\delta}
$$

\subsection{Salinity Profiling}

EC measurements were undertaken to study the extent of the salinization. Vertical profiles of monitoring and production wells were obtained using YSI 600XLM Sonde (YSI Incorporated, 2014) connected to a laptop computer. The sonde was calibrated using conductivity standard placed in a pre-rinsed and dry calibration cup, with the probe end of the sonde immersed into the solution and calibrated according to the procedure in the manual. The sonde was connected to a $120 \mathrm{~m}$ length cable and lowered down the well from surface to the well base, recording EC data along the way. The calibrated 600 XLM Sonde has a conductivity range of 0-100,000 $\mu \mathrm{S} . \mathrm{cm}^{-1}$ with an accuracy of measurements $\pm 0.5 \%$ reading $+1 \mu \mathrm{S} . \mathrm{cm}^{-1}$, and can operate in a temperature range $-5^{\circ} \mathrm{C}$ to $45^{\circ} \mathrm{C}$ up to $200 \mathrm{~m}$ depth (Somaratne, 2014).

\section{Results and Discussion}

\subsection{Analysis of Legacy Issues: History of Demand-Driven Groundwater Pumping}

The capacity of the basin has been assessed by three long-term pumping tests conducted in 1959-60. In lens A, production well PB A has been pump tested for a duration of 30 days to determine safe yield. The well yielded a supply at a rate of $14.7 \mathrm{~L} . \mathrm{s}^{-1}$ with a drawdown of $5.6 \mathrm{~m}$. During the pumping test, salinity remained constant at $838 \mathrm{mg} \cdot \mathrm{L}^{-1}$. This led to the conclusion that there would be no deterioration of water quality during prolonged pumping despite the well being located $345 \mathrm{~m}$ from the shore of Sleaford Mere, a saline lake. Two pumping tests have been carried out in lens B. The production well PB G was pump tested for 11 days at a rate of $13.5 \mathrm{~L} \cdot \mathrm{s}^{-1}$. At the end of the day 1 of the pump test, salinity had increased from the original value of $855 \mathrm{mg} . \mathrm{L}^{-1}$ to $1214 \mathrm{mg} . \mathrm{L}^{-1}$ and at the end of the test on the $11^{\text {th }}$ day; salinity was $1796 \mathrm{mg} \cdot \mathrm{L}^{-1}$. The movement of salinity may have been caused by upconing of brackish water from the deeper sediments. Pumping test of production well PB F was also

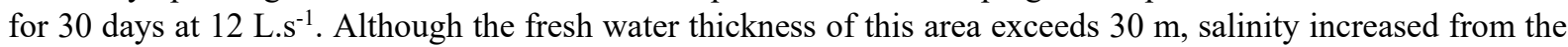
initial value of $838 \mathrm{mg} . \mathrm{L}^{-1}$ to $940 \mathrm{mg} . \mathrm{L}^{-1}$ during the first 14 days and thereafter remained constant. Neither recharge to the freshwater lenses nor the water balance had been assessed, and a precautionary approach to groundwater extraction was not followed. The apparent driver at the time, for managing the basin was to meet the demand for the township.

Based on above pump test results, it was concluded that a "large body of water is located in three areas of the Lincoln Basin. It has been considered that this water could be used to augment water supplies to Port Lincoln" (Shepherd, 1959). As a result, three areas were developed to supply $2 \times 10^{6} \mathrm{~m}^{3}$ per year distributed across three lenses as lens A: four wells to supply $0.84 \times 10^{6} \mathrm{~m}^{3}$, lens B: four wells to supply $0.5 \times 10^{6} \mathrm{~m}^{3}$ and lens C: four wells to supply $0.66 \times 10^{6} \mathrm{~m}^{3}$.

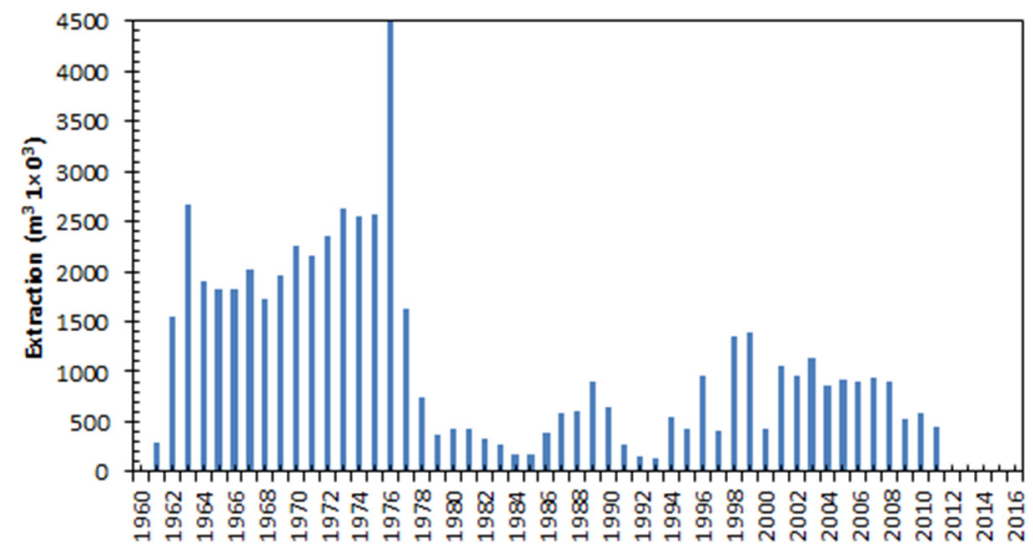

Figure 4. Groundwater extraction from Lincoln Basin 
Subsequently, Shepherd (1962) revised the initial estimate of the basin yield to approximately $1.82 \times 10^{6} \mathrm{~m}^{3}$ per year, followed by Painter (1970) with an estimated safe yield to $2.33 \times 10^{6} \mathrm{~m}^{3}$. Groundwater extraction from the basin increased since 1962 to reach maximum extraction of $4.5 \times 10^{6} \mathrm{~m}^{3}$ per year in 1976 (Figure 4). Following an additional three pumping tests conducted in 1972, Selby (1972) announced a need for re-assessment of the safe yield of Lincoln freshwater lenses A, B and C. However, groundwater extraction dramatically reduced as a result of increasing salinity and the development of the adjacent Uley South Basin in 1976. By 1976, the basin's average salinity has increased to over $1000 \mathrm{mg} . \mathrm{L}^{-1}$. The aquifer was fully utilized for only 16 years.

Since monitoring began in lens A, water levels in the near coast wells dropped by $1 \mathrm{~m}$ and in the inland wells dropped by $2 \mathrm{~m}$ for the same period. A similar observation is made for lens $\mathrm{B}$ and $\mathrm{C}$ where, in lens $\mathrm{B}$, the near-coast wells dropped by $0.3 \mathrm{~m}$ and the further inland wells by $0.5 \mathrm{~m}$. Water level decline in lens B is smaller than lens A due to coastal buffering. In lens $C$, the near coast wells dropped by $0.8 \mathrm{~m}$ and inland wells dropped by $1.5 \mathrm{~m}$.

\subsection{Recharge}

Recharge rate to the aquifer was assessed using two methods; water-table fluctuation (WTF) (Healy \& Cook. 2002) and the conventional chloride mass balance (CMB) method (Eriksson \& Khunakasem, 1969).

The WTF method is based on relating changes in measured water table elevation with changes in the amount of water in aquifer storage:

$$
\mathrm{R}=\mathrm{S}_{\mathrm{y}} \frac{\Delta \mathrm{h}}{\Delta \mathrm{t}}
$$

where $\mathrm{R}$ is recharge rate, $\mathrm{S}_{y}$ is specific yield, and $\Delta \mathrm{h}$ is the peak watertable rise attributed to the recharge at time $\Delta \mathrm{t}$ (Healy \& Cook, 2002).

For the conventional CMB, recharge is estimated for a closed basin where the ambient groundwater chloride concentration is much higher than the chloride concentration of surface runoff. The conventional CMB equation for recharge volume estimate can be expressed as:

$$
\mathrm{R}=\frac{\mathrm{Pc} \mathrm{p}+\mathrm{D}}{\mathrm{c}_{\mathrm{g}}}
$$

where $\mathrm{R}$ is the recharge rate, $\mathrm{P}$ is the long-term average annual rainfall $\left(509 \mathrm{~mm}^{\mathrm{m}}\right.$.ear $\left.\mathrm{r}^{-1}\right), \mathrm{c}_{(\mathrm{p}+\mathrm{D})}$ is the mean chloride concentration of rainwater $\left(\mathrm{mg} . \mathrm{L}^{-1}\right)$ including a contribution from dry deposition, and $\mathrm{c}_{\mathrm{g}}$ is the groundwater chloride concentration obtained at locations given in Figure 5.

In the absence of direct measurement, the $c_{\mathrm{p}+\mathrm{D}}$ can be estimated from Hutton (1976) using:

$$
\mathrm{c}_{\mathrm{p}+\mathrm{D}}=35.45 \times\left\{\frac{0.99}{\mathrm{~d}^{0.25}}-0.23\right\}
$$

where " $\mathrm{d}$ " is the distance in $\mathrm{km}$ from the ocean in the prevailing wind direction. Thus, for Lincoln Basin centre of the $\mathrm{A}, \mathrm{B}$ and $\mathrm{C}$ lenses at $3,2.5$ and $5 \mathrm{kms}$ from coast to the centre of the basin gives $\mathrm{c}_{\mathrm{p}+\mathrm{D}}$ of $18.4,19.5$ and

\begin{tabular}{|c|c|c|c|c|c|}
\hline Lens & $\begin{array}{l}\mathrm{R}\left(\mathrm{mm} \cdot \mathrm{year}^{-1} \text { ) }\right. \\
\text { (WTF method) }\end{array}$ & $\begin{array}{l}\mathrm{R}\left(\mathrm{mm} \cdot \text { year }^{-1}\right) \\
(\mathrm{CMB} \text { method })\end{array}$ & $\begin{array}{c}\text { WTF and CMB } \\
\text { Average, R } \\
\left(\text { mm.year }{ }^{-1}\right)\end{array}$ & Lens Area $\left(\mathrm{km}^{2}\right)$ & $\begin{array}{c}\text { Total Annual } \\
\text { Recharge Volume } \\
\left(\mathrm{m}^{3}\right)\end{array}$ \\
\hline A & 54 & 27 & 40.5 & 20.5 & $0.83 \times 10^{6}$ \\
\hline B & 21 & 28 & 24.5 & 12 & $0.29 \times 10^{6}$ \\
\hline $\mathrm{C}$ & 15 & 19.6 & 17.3 & 30 & $0.52 \times 10^{6}$ \\
\hline
\end{tabular}
$15.2 \mathrm{mg} \cdot \mathrm{L}^{-1}$ respectively. Calculated recharge is summarised in Table 1.

Table 1. Summary of recharge to the groundwater lenses

Thus total recharge to the lens is estimated at $1.6 \times 10^{6} \mathrm{~m}^{3}$ per year which is less than the annual groundwater extraction from the lens during the 1963-1977 periods (average 2.14 $\times 10^{6} \mathrm{~m}^{3}$ ) (Figure 4).

As the annual extraction exceeded the annual recharge, mining of the groundwater storage has occurred in the basin leading to saline intrusion, upconing and lateral flow of brackish water into wellfield areas. The freshwater zone had been delineated with a salinity of $1360 \mathrm{mg} \cdot \mathrm{L}^{-1}$ as the boundary between freshwater and brackish water. Salinity of the upper $15 \mathrm{~m}$ of groundwater within the lenses varied from $580 \mathrm{mg} . \mathrm{L}^{-1}$ to $970 \mathrm{mg} . \mathrm{L}^{-1}$. Figure 6 shows the depth of freshwater as mapped by Sheppard (1959), and the calculated volume of freshwater in storage is presented in Table 2 . 


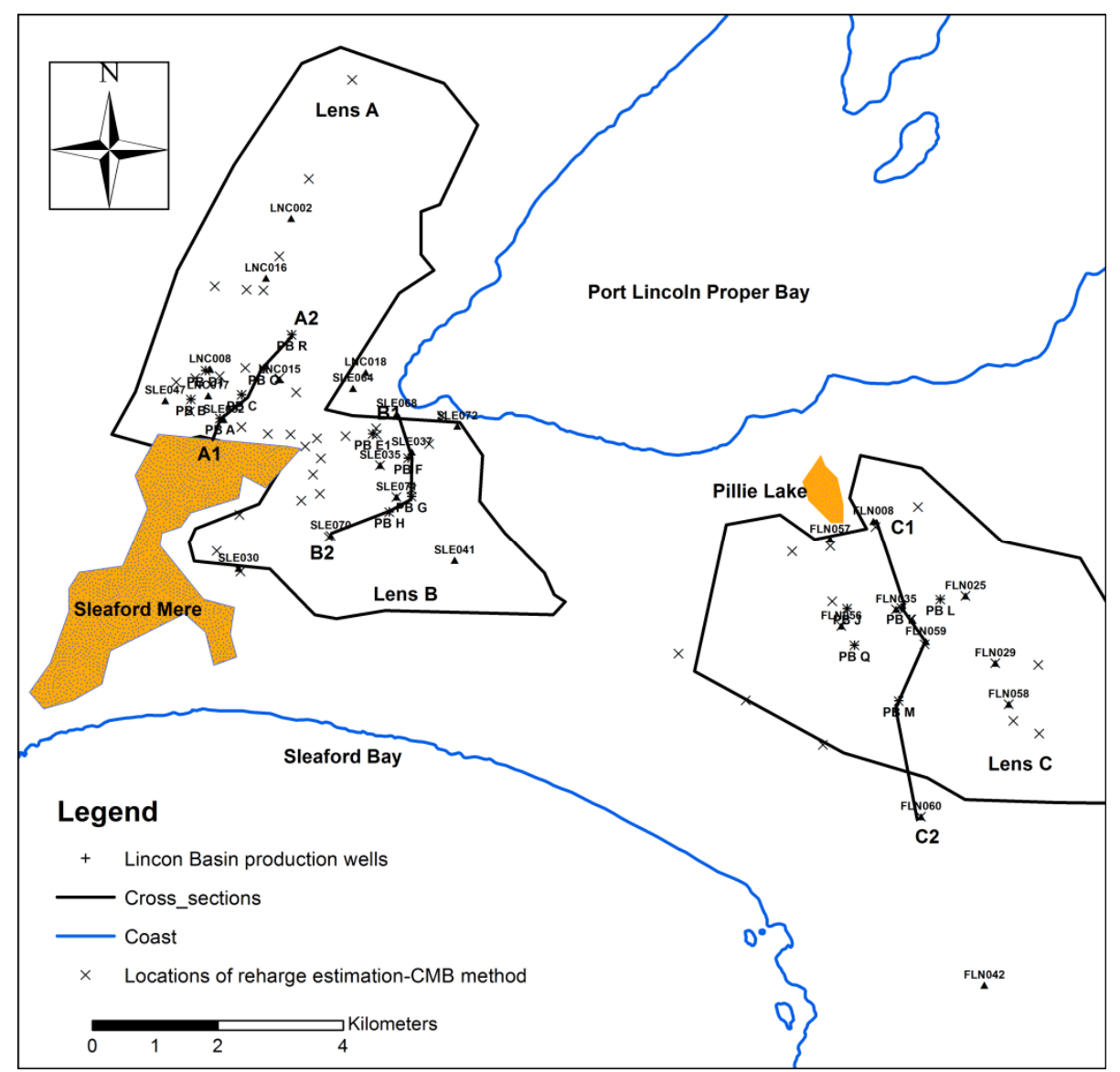

Figure 5. Locations of recharge estimate using CMB method and cross sections

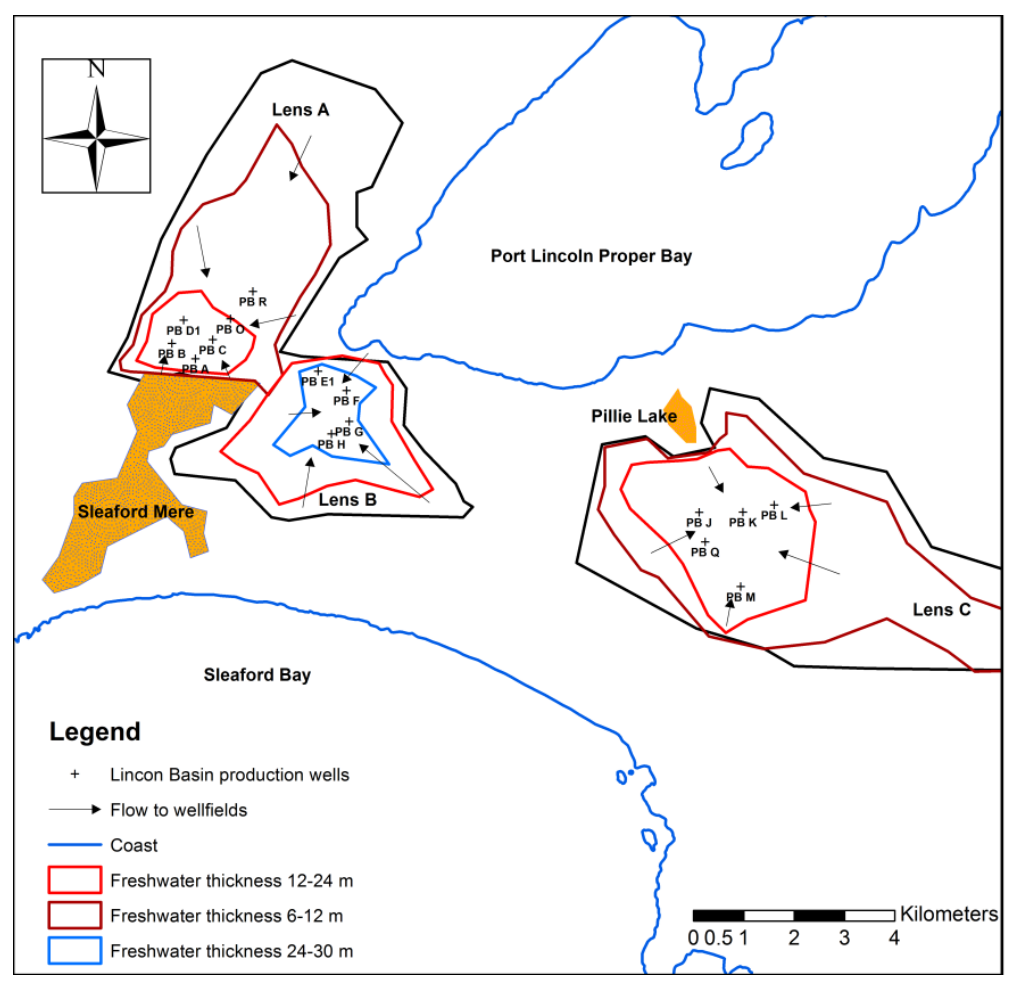

Figure 6. Depths of freshwater-1959 (after Shepherd, 1959) 
Table 2. The average estimated storage volume of fresh water in 1959 (aquifer porosity of 0.3 was taken)

\begin{tabular}{ccccccc}
\hline \multirow{2}{*}{ Lens } & \multirow{2}{*}{ Total area $\left(\mathrm{km}^{2}\right)$} & \multicolumn{5}{c}{ Area of freshwater thickness $\left(\mathrm{km}^{2}\right)$} \\
\cline { 3 - 7 } & & $0-6 \mathrm{~m}$ & $6-12 \mathrm{~m}$ & $12-24 \mathrm{~m}$ & $24-30 \mathrm{~m}$ & The volume of water $\left(\times 10^{6} \mathrm{~m}^{3}\right)$ \\
\hline \multirow{2}{*}{$\mathrm{A}$} & 20.5 & 20.5 & 11.5 & 2.5 & - & 63 \\
$\mathrm{~B}$ & 12 & 12 & 7.5 & 7.5 & 2.4 & 51.3 \\
$\mathrm{C}$ & 30 & 30 & 22 & 8.7 & - & 133.2 \\
\hline
\end{tabular}

The total freshwater volume in storage in the lenses was $247 \times 10^{6} \mathrm{~m}^{3}$, while the total volume extracted was $35 \times 10^{6} \mathrm{~m}^{3}$. This exceeded the estimated recharge volume over the same 15 year period of, about $24 \times 10^{6} \mathrm{~m}^{3}$ indicating mining of the freshwater lenses by $11 \times 10^{6} \mathrm{~m}^{3}$.

\subsection{Salinity Variation Along Selected Cross Sections}

Within lens A, the groundwater salinity data obtained during the investigation drilling in late 1950's and early 1960's showed a TDS less than 1000 mg.L ${ }^{-1}$ (Figure 7). No significant salinity stratification was observed in the vicinity of the wellfield. At present, groundwater of the highest salinity $\left(1200-1600 \mathrm{mg} . \mathrm{L}^{-1}\right)$ is found in PB C, PB O and PB R (Figure 7). The well PB R was constructed in 1975 with a salinity of $1160 \mathrm{mg} . \mathrm{L}^{-1}$ at the time and increased to $1569 \mathrm{mg} . \mathrm{L}^{-1}$ in 2011 . One month later the salinity had increased to a value of over $2600 \mathrm{mg} . \mathrm{L}^{-1}$, as the extraction continued. The higher salinity of PB C, PB O, and PB R are north of lower salinity zone and are within the shallow freshwater zone (6-12 m depth, Figure 6).

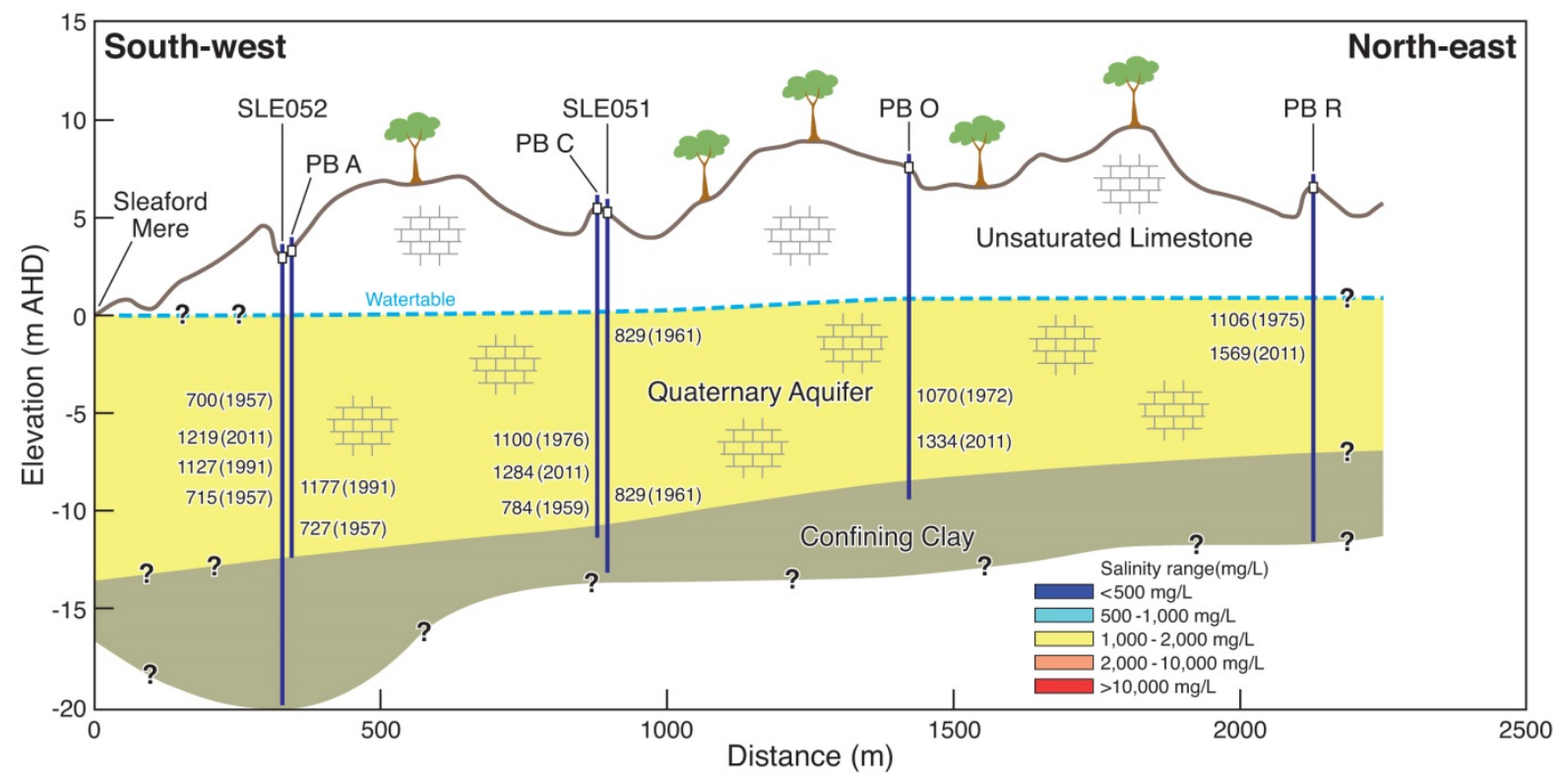

Figure 7. Salinity variation in north-south cross-section in lens A (after Zulfic \& Somaratne, 2012)

EC profiling conducted in 2008 shows significant EC stratification in the observation well SLE052 where EC increased about $700 \mu \mathrm{S} . \mathrm{cm}^{-1}$ over a $9 \mathrm{~m}$ production zone interval (Figure 8). Invasion of higher salinity water from the Sleaford Mere may be the cause of the EC increase. The salinity profile of 2017 indicates apparent stability has been reached in the profile. Further up gradient well LNC017, located $660 \mathrm{~m}$ from the Sleaford Mere, shows a vertical stratification of about $550 \mu \mathrm{S} . \mathrm{cm}^{-1}$. EC stratification in PB B and PB C are similar to the LNC017, and is most likely the result of upconing and lateral movement of groundwater towards the production wells. 

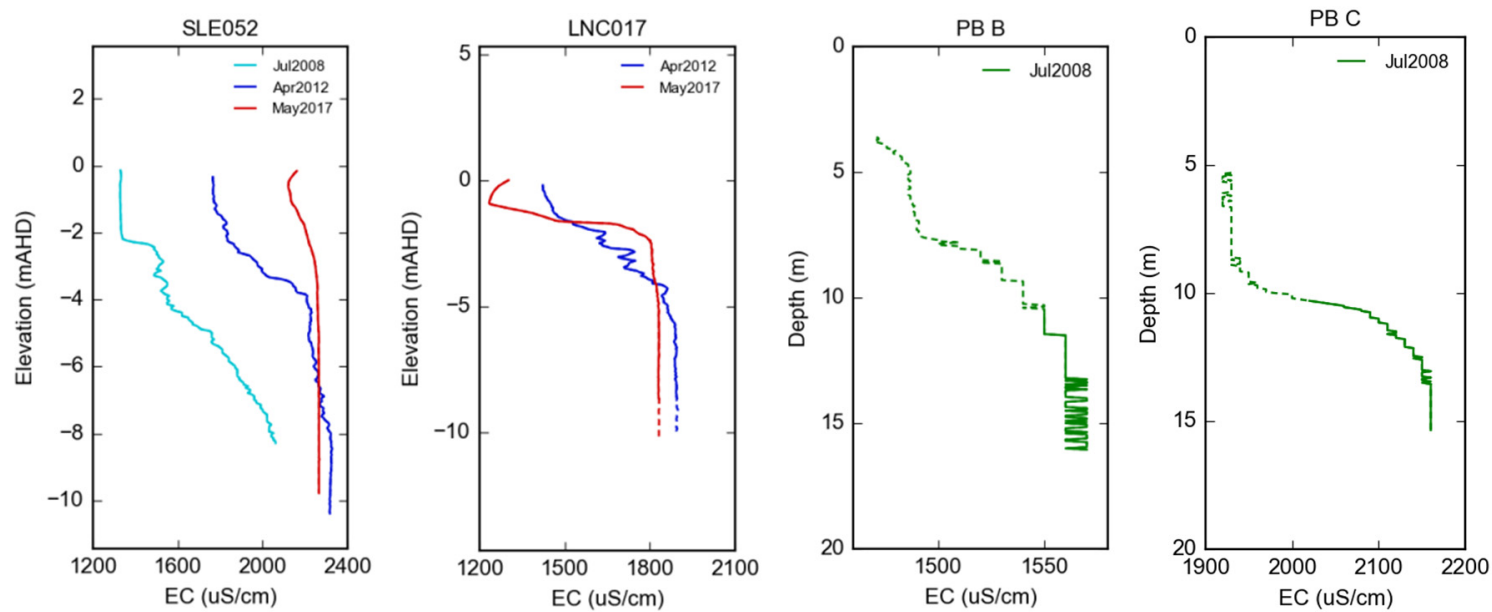

Figure 8. EC profiles in Lens A (solid line indicates the production zone of the well)

Salinity variation across the lens B in the north-south direction is given in Figure 9. Salinity stratification was not observed during investigation drilling, and an aquifer thickness of about $30 \mathrm{~m}$ contained freshwater of TDS $<1000 \mathrm{mg} . \mathrm{L}^{-1}$. The upper freshwater aquifer is underlain by brackish and saline groundwater (Figure 9). Production wells are constructed in the upper half of the aquifer leaving an approximate $15 \mathrm{~m}$ gap between the well bottom and the higher salinity layers. Higher salinity water, up to $10500 \mathrm{mg} . \mathrm{L}^{-1}$ was found in the Tertiary

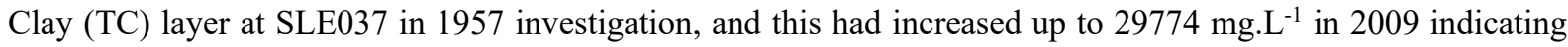
saline wedge has moved into the aquifer. The original salinity stratification in the QL aquifer and TC layer can be seen in monitoring well SLE034 where the salinity of the TC increased from $1270 \mathrm{mg} . \mathrm{L}^{-1}$ to $31460 \mathrm{mg} . \mathrm{L}^{-1}$ within approximately $12 \mathrm{~m}$ depth. As the pumping continued upconing of the transition zone has occurred increasing the salinity of production wells (Figure 9). As described above, this phenomenon was observed during the initial pumping tests.

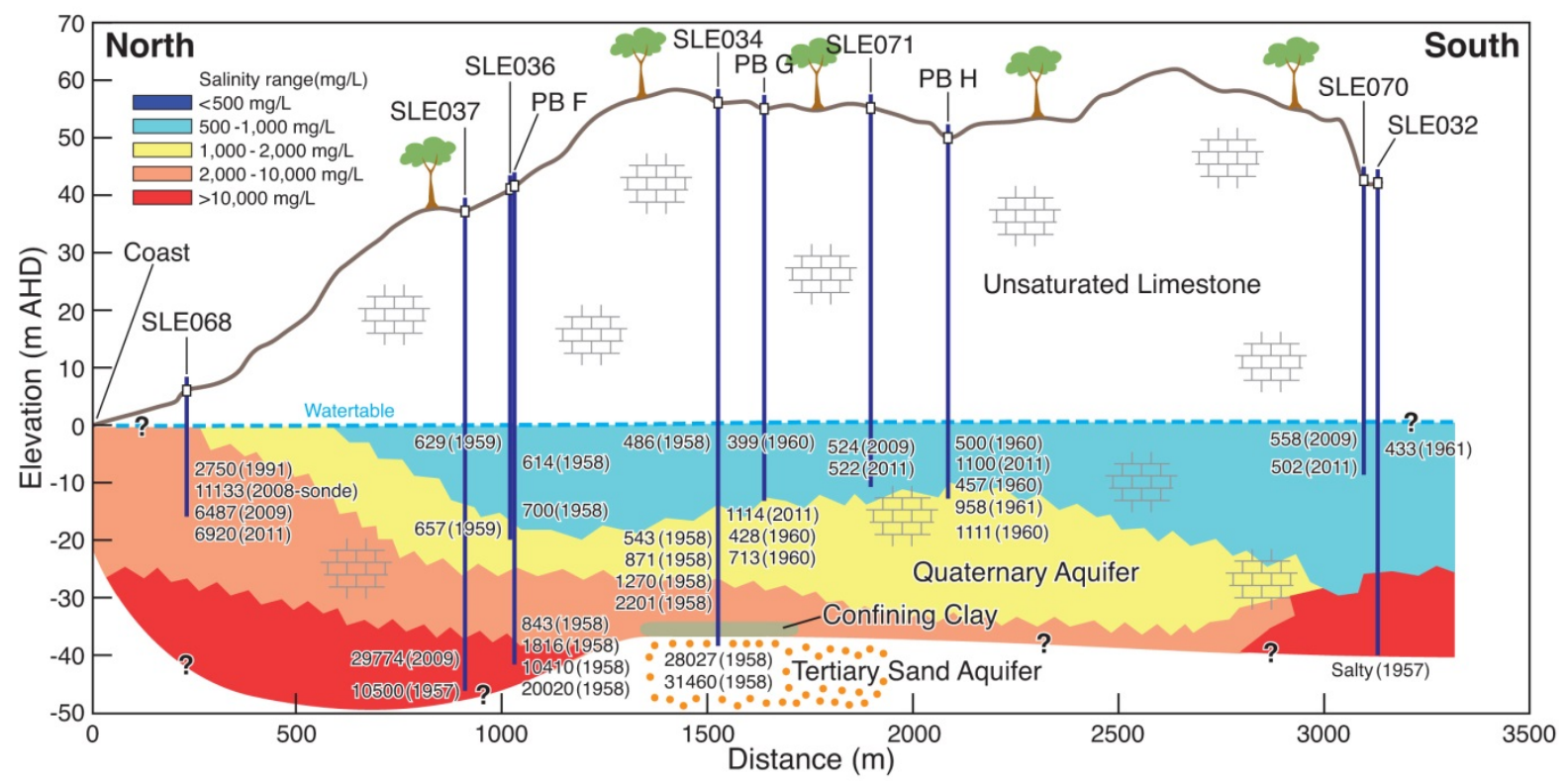

Figure 9. Salinity variation in north-south cross-section in lens B (after Zulfic \& Somaratne, 2012) 

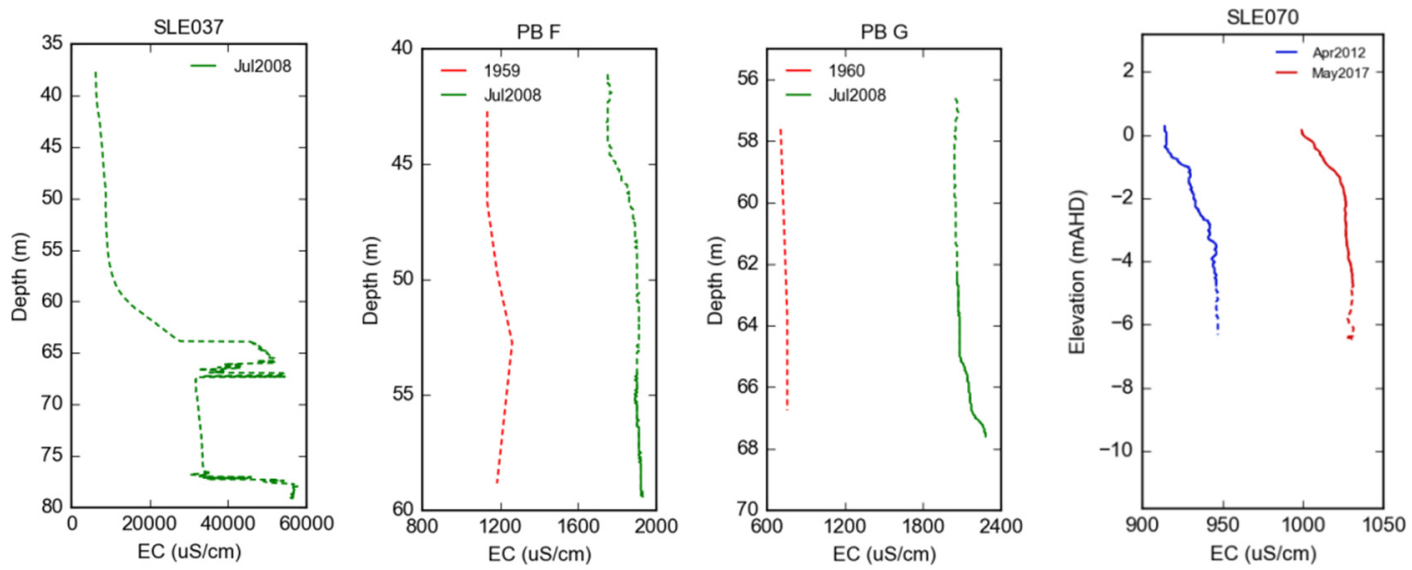

Figure 10. EC profiles in Lens B (solid line indicates the production zone EC; 1959 and 1960 EC data for PB F and PB G were collected during well drilling)

Monitoring well SLE068 is situated $275 \mathrm{~m}$ from the coastline in an area where the aquifer is saline (Figure 9). EC measurement conducted in 2008 (EC of $11133 \mu \mathrm{S} . \mathrm{cm}^{-1}$ is equivalent to $6123 \mathrm{mg} . \mathrm{L}^{-1}$ ) shows stratification in the well with stark variation at $10 \mathrm{~m}$ below sea level, indicative of the position of the saline wedge. Monitoring well SLE037, located in the vicinity of PB F, was cased to $78 \mathrm{~m}$ with a production zone of 78-80.5 m, hence completed in the bottom part of the aquifer with $\mathrm{EC}$ of $\sim 60000 \mu \mathrm{S} . \mathrm{cm}^{-1}$. A significant increase in EC without stratification in PB F and PB G (Figure 10) is indicative of brackish water movement into wellfield area rather than upconing. The well SLE070, located about $2450 \mathrm{~m}$ from the Port Lincoln Proper and $1600 \mathrm{~m}$ from the Sleaford Mere, shows $75 \mu \mathrm{S} \mathrm{cm}^{-1}$ increase in EC from 2012 to 2017. This indicates that long after the cessation of extraction, groundwater salinity continues to increase in the basin. Thus, salinization of Lincoln lens B is considered due to both seawater intrusion and brackish water movement towards the production wells.

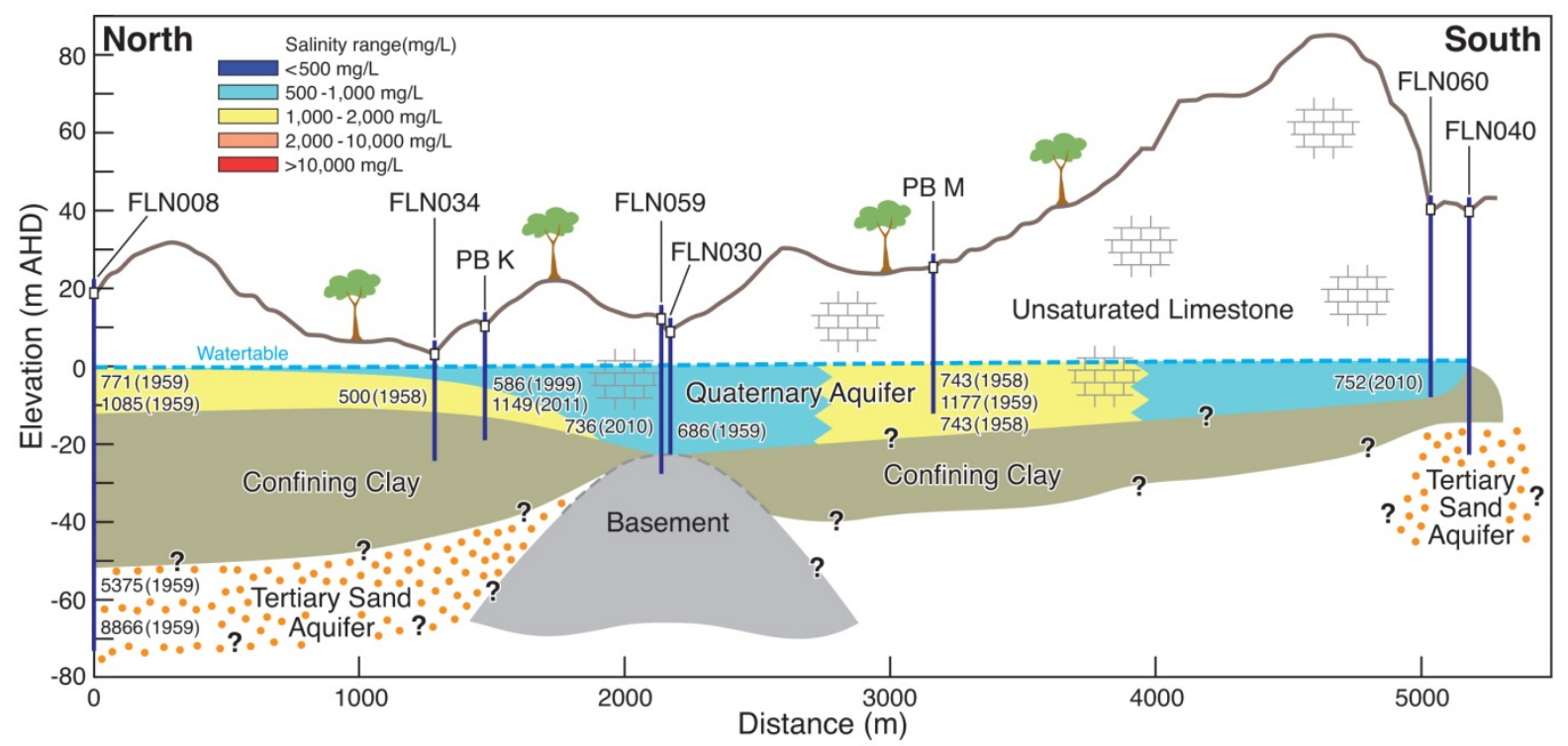

Figure 11. Salinity variation in north-south cross-section in lens C (after Zulfic \& Somaratne, 2012)

The Lincoln lens $\mathrm{C}$ is located in the most eastern part of the basin in an area south of Pillie Lake, where good quality water extends to the bottom of the Quaternary Limestone aquifer. However, in some areas, the aquifer is not continuous, and dry clayey lenses occur between relatively thin water-bearing horizons (Figures 11). The saturated thickness of the aquifer containing water of salinity $<1000 \mathrm{mg} \cdot \mathrm{L}^{-1}$ is approximately $15-20 \mathrm{~m}$. The Quaternary Limestone aquifer is underlain by sediments considered to be a confining layer. The Tertiary Sand (TS) aquifer was encountered below the confining layer north of wellfield (FLN008) and contains groundwater 
with salinity between $5375-8886 \mathrm{mg} \cdot \mathrm{L}^{-1}$. A slight salinity stratification was observed during drilling of production wells PB K, PB L and monitoring well FLN035. At present, groundwater salinity of four production

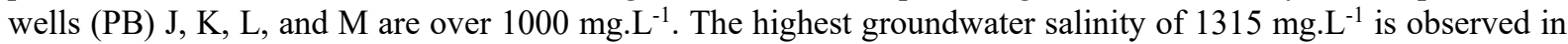
the production well PB Q. Similar to the lens B; it appears that upconing of brackish water from the TC layer and lateral movement of brackish water into the wellfield area are considered as the mechanisms of salinization of lens C.

Monitoring (FLN056 and FLN059) and production (PB M and PB Q) wells in the lens C are located in the central part of basin within 3.5-4 km of the nearest coastline. EC profiles of FLN056 show $300 \mu \mathrm{S} . \mathrm{cm}^{-1}$ increase

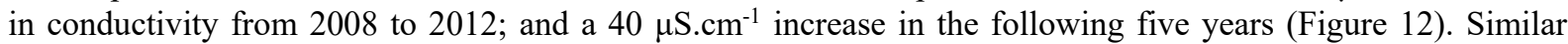
minor increases $\left(30 \mu \mathrm{S} . \mathrm{cm}^{-1}\right)$ found in FLN059 indicate the profiles have reached apparent stability. EC profiles taken in 2008 show no stratification through the production zones in PB M and PB Q. An increase in EC by 360 $\mu \mathrm{S} . \mathrm{cm}^{-1}$ in PB Q without stratification may be an indication of the lateral flow of groundwater into the well from areas with higher salinity.
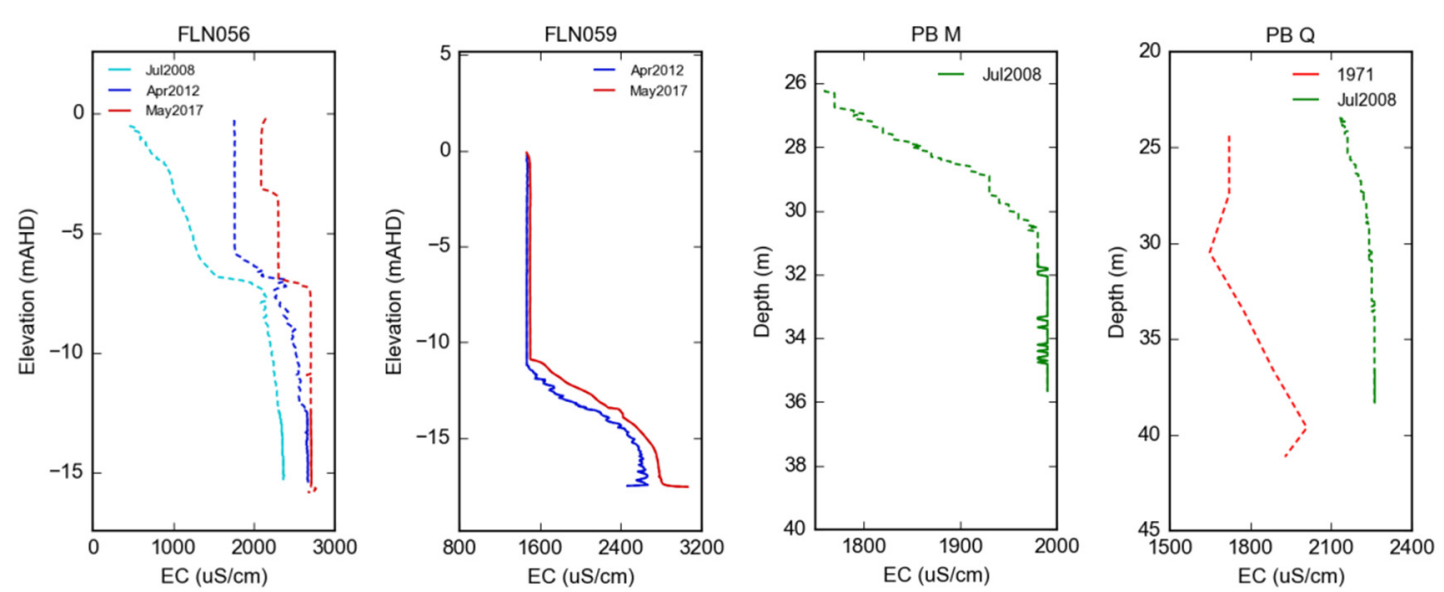

Figure 12. EC profiles in Lens C (solid line indicates protection zone EC, 1971 data for PB Q collected during well drilling)

\subsection{Comparison of the Pre-Development and Contemporary Distance to the Toe of the Saline Wedge From the Coast}

The position of the saline wedge and the properties of the transition zone in coastal aquifers depend on aquifer type and thickness, hydraulic head, heterogeneity of aquifer parameters and geological layers, recharge, groundwater extraction, and dispersion characteristics. Apart from seawater, saline groundwater can also originate from non-marine sources due to transpiration by vegetation, dissolution of salt deposits, mineral weathering and, in arid and semi-arid regions, evaporation of meteoric water or surface water bodies (Herczeg et al., 2001).

For the analyses, aquifer depth (d) was taken as the average of the wellfield area in each lens, hydraulic conductivity was obtained from the average of pump tested transmissivities, and recharge values were taken from Table 1. The net recharge $\left(R_{n}\right)$ was the rainfall recharge minus annual pumping distributed over the lens area. Annual pumping exceeded the annual recharge in lenses B and C, and net recharge becomes negative as given in Table 3. Water levels at near-coastal wells are below sea level implying unstable interface conditions as the toe of the saline wedge may still be moving inland.

Calculated pre-development values of $\mathrm{x}_{\mathrm{T}}$ using equation (9) for lens are given in Table 3. During post-development, the saline wedge in lens A has moved to $184 \mathrm{~m}$ from the coastline, which is considered as a minor saline intrusion. For lenses $\mathrm{B}$ and $\mathrm{C}$ post development, the $\mathrm{x}_{\mathrm{T}}$ result is unstable as net recharge to the aquifers is negative. 
Table 3. Parameters and results of theoretical distance to the toe of the saline wedge $\left(\mathrm{x}_{\mathrm{T}}\right)$ using equation (9)

\begin{tabular}{|c|c|c|c|c|c|c|c|c|c|c|c|}
\hline Lens & $\mathrm{L}(\mathrm{m})$ & $\mathrm{d}(\mathrm{m})$ & $\mathrm{K}\left(\mathrm{m} \cdot \mathrm{d}^{-1}\right)$ & Well & $\mathrm{x}_{\mathrm{b}}(\mathrm{m})$ & $\mathrm{h}_{\mathrm{b}}(\mathrm{m})$ & $\mathrm{R}\left(\mathrm{m} \cdot \mathrm{d}^{-1}\right)$ & $\mathrm{Q}_{\mathrm{w}}\left(\mathrm{m} \cdot \mathrm{d}^{-1}\right)$ & $\mathrm{R}_{\mathrm{n}}\left(\mathrm{m} \cdot \mathrm{d}^{-1}\right)$ & $\mathrm{q}_{0}\left(\mathrm{~m}^{2} \cdot \mathrm{d}^{-1}\right)$ & $\mathrm{x}_{\mathrm{T}}(\mathrm{m})$ \\
\hline \multicolumn{12}{|c|}{ Pre-development 1960} \\
\hline A & 6600 & 15 & 192 & LNC002 & 3760 & 4.14 & $11.1 \mathrm{E}-5$ & 0 & $11.1 \mathrm{E}-5$ & 3.67 & 128 \\
\hline B & 3500 & 30 & 122 & SLE035 & 1070 & 0.61 & $6.57 \mathrm{E}-5$ & 0 & $6.57 \mathrm{E}-5$ & 0.86 & 1318 \\
\hline $\mathrm{C}$ & 6200 & 17 & 118 & FLN029 & 5100 & 1.58 & 4.73E-5 & 0 & $4.73 \mathrm{E}-5$ & 0.68 & 385 \\
\hline \multicolumn{12}{|c|}{ Post-development 1976} \\
\hline A & 6600 & 15 & 192 & LNC002 & 3760 & 3.52 & $11.1 \mathrm{E}-5$ & $11 \mathrm{E}-5$ & $1.3 \mathrm{E}-6$ & 3.0 & 184 \\
\hline B & 3500 & 30 & 122 & SLE035 & 1070 & 0.41 & $6.57 \mathrm{E}-5$ & $11.5 \mathrm{E}-5$ & $-4.93 \mathrm{E}-5$ & 0.16 & Unstable \\
\hline $\mathrm{C}$ & 6200 & 17 & 118 & FLN029 & 5100 & 1.07 & $4.73 \mathrm{E}-5$ & $6.0 \mathrm{E}-5$ & $-1.28 \mathrm{E}-5$ & 0.47 & Unstable \\
\hline
\end{tabular}

The saline wedge movement due to multiple well pumping was analysed combining equations (5) and (15) for aquifer strips covering well fields given in Figure 14. The y-axes of the aquifer strips approximated the coastline. It is assumed fully penetrating pumping wells extract groundwater at maximum capacity simultaneously. Uniform maximum pumping rates of $575 \mathrm{~m}^{3}$.day ${ }^{-1}$ for lens A, $342 \mathrm{~m}^{3}$.day ${ }^{-1}$ for lens B and $452 \mathrm{~m}^{3}$.day ${ }^{-1}$ for lens $\mathrm{C}$ were applied for all wells in respective lenses. Using aquifer parameters given in Table 3 , the interface location $\left(\mathrm{x}_{\mathrm{T}}\right)$ as a function of $\mathrm{y}$ was determined and is given as an inset in Figure 13. The pre-development interfaces of lenses A, B and C are parallel to the coastline and are $153 \mathrm{~m}, 1598 \mathrm{~m}$ and $642 \mathrm{~m}$ respectively, which are slightly higher than values given in Table 3 using equation (9). The maximum distance of interface movement from its original position is: $35 \mathrm{~m}$ in lens A, $337 \mathrm{~m}$ in lens B and $188 \mathrm{~m}$ in lens C. This indicates saline intrusion due to the interface movement may not be the only cause of increased salinity.

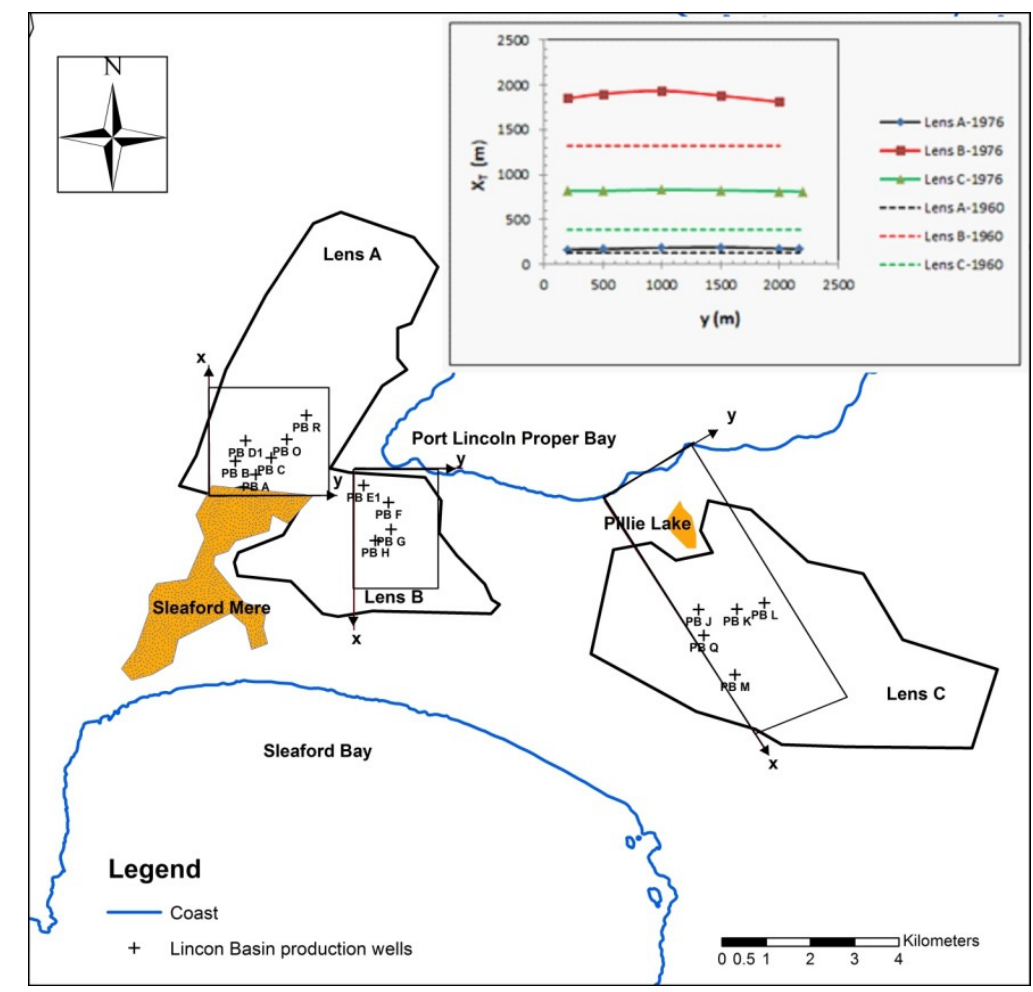

Figure 13. Comparison of distance to the toe of the saline wedge due to multiple well pumping

Applying the methodology of $\mathrm{x}_{\mathrm{T}}$ calculation outlined above, the uncertainty in the hydrogeological parameters and pumping rates were not modelled. Calculated $\mathrm{x}_{\mathrm{T}}$ might vary depending on parameter variation. The value of $\mathrm{x}_{\mathrm{T}}$ as a function of $\mathrm{y}$ is depicted in Figure 13 inset, and is uniform over the entire coastline. This could be due to pumping wells that are located further away from the coastline and therefore have minimal influence. The maximum value for the mean of $\mathrm{x}_{\mathrm{T}}$ corresponds to the $\mathrm{y}$ value where maximum extraction takes place. For example, in lens $\mathrm{B}$ at $\mathrm{y}=1000 \mathrm{~m}$, the maximum intrusion extent $\left(\mathrm{x}_{\mathrm{T}}\right)$ was equal to $1935 \mathrm{~m}$ indicating the interface has reached beyond the production well PB E1, PB F and monitoring wells SLE035, SLE037 which are within 
$1000 \mathrm{~m}$ zone of the coastline. The depth of PB F well $(57.5 \mathrm{~m})$ (Figure 14) is approximately $-17.5 \mathrm{~m}$ AHD elevation. Comparing PB F well with SLE035 well shows that at $-17.5 \mathrm{~m} \mathrm{AHD,} \mathrm{EC} \mathrm{of} \mathrm{the} \mathrm{groundwater} \mathrm{is} \mathrm{about}$ $1050-1250 \mu \mathrm{S} . \mathrm{cm}^{-1}$. The EC profile of monitoring well SLE037 shows that EC equivalent to sea water is found at elevation -28 m AHD. This shows that saline water is present $10.5 \mathrm{~m}$ under PB F, and upconing could occur under pumping conditions. Since pre-development in 1959, the EC of PB F has increased by about $700 \mu \mathrm{S} . \mathrm{cm}^{-1}$.
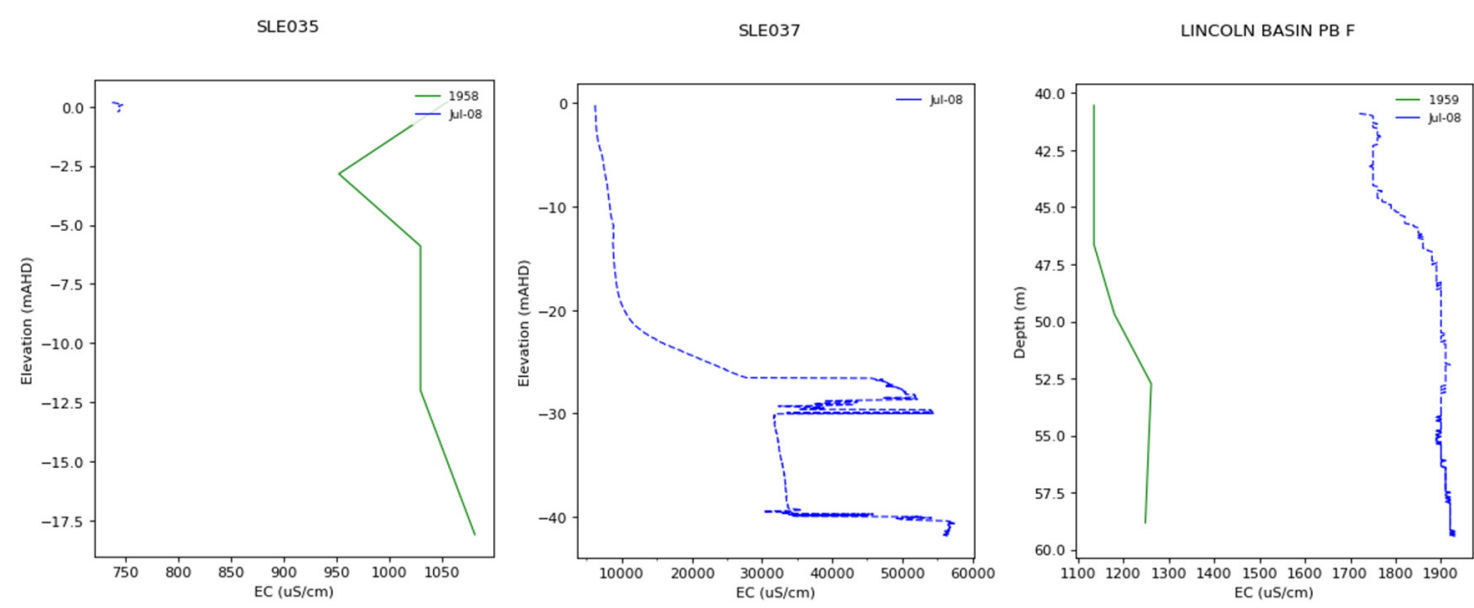

Figure 14. EC profiles to assess depth to saline interface

For each pumping well at maximum discharge rate, the transient interface location $(\zeta)$ directly underneath the well was calculated using equation (16). This results in interface rise under pumping wells in lens A of $3.8 \mathrm{~m}$, lens $\mathrm{B}$ of $0.5 \mathrm{~m}$, and in lens $\mathrm{C}$ about $0.7 \mathrm{~m}$. The critical pumping rates determined using equation (18), results in near-coast wells in lens A; PB A and PB B of about 3-5 L.s $\mathrm{s}^{-1}$ and in PB C and PB D of about 65-82 L. s $^{-1}$. In lens $\mathrm{B}$, the critical pumping rate for all wells is about $60 \mathrm{~L} \cdot \mathrm{s}^{-1}$ and in lens $\mathrm{C}$ it is in the range of 18-50 L.s $\mathrm{s}^{-1}$. The higher rates calculated using equation (18) is unrealistic as it assumes the interface reaches the well bottom. In reality, wells will be abandoned before this happens as slight upconing may induce increased salinity of production wells.

\subsection{Future Use of the Lincoln Basin}

Future use of the Lincoln Basin as a water supply source is currently not possible due to the risk of further increase in salinity. However, assessment was made to determine what would have been the safe allocation on the basis of risk to the aquifer and environment; and the development risk. For areas where groundwater knowledge is limited or validated groundwater models are not available to apply modelling and optimization techniques for allocation, an alternative approach such as risk-based groundwater allocation (Bish et al., 2006; Department of Water, 2011) can be used. Using the risk-based approach, the allocation limit is based on a proportion of the estimated average annual recharge to the aquifer. The proportion is determined by considering in-situ risk (risk to the aquifer and dependent ecosystem) and development risk (risk to the consumptive use), and the ability to manage those risks.

Table 5. Risk matrix for determining proportion of recharge for allocation (Somaratne \& Ashman, 2018)

\begin{tabular}{llll}
\hline & \multicolumn{2}{c}{ Proportion of Recharge } \\
\hline High In-situ Risk & $5 \%$ & $25 \%$ & $50 \%$ \\
Medium In-situ Risk & $25 \%$ & $50 \%$ & $60 \%$ \\
Low In-situ Risk & $50 \%$ & $60 \%$ & $70 \%$ \\
& Low Development Risk & Medium Development Risk & High Development Risk \\
\hline
\end{tabular}

According to Table 5, with high in-situ risk and medium development risk, the Lincoln Basin allocation as a proportion of recharge is $25 \%$ of the annual recharge. Thus maximum abstraction limits for lenses $\mathrm{A}, \mathrm{B}$ and $\mathrm{C}$ would have been $210 \times 10^{3} \mathrm{~m}^{3}, 72 \times 10^{3} \mathrm{~m}^{3}$ and $130 \times 10^{3} \mathrm{~m}^{3}$ giving total extraction limit of $412 \times 10^{3} \mathrm{~m}^{3}$. 


\section{Concluding Remarks}

Over-pumping of coastal aquifers can cause water levels to drop resulting in seawater intrusion into the aquifer. While subsequent recharge can help in the recovery of water levels, flushing of the seawater will only be partially successful, as much of the salinity remains behind (Saltrans, 2004). This is because freshwater tends to flow along the permeable paths, leaving saltwater entrapped in the less permeable regions. Dispersion and swelling of clays, induced by saltwater, may further reduce permeability thus affecting the ability of the fresh water to displace the seawater (ibid). Moreover, since freshwater floats on top of saltwater, salinity is also trapped in the deeper regions at the aquifer bottom. Flushing salinity from these deeper regions may require a lot of freshwaters to flow seawards. Seawater flows easily inland but, given the significant density difference, is very hard to displace with freshwater. Greater volumes of freshwater may be required to freshen-up the aquifer than was gained from overpumping the aquifer in the first place (Saltrans, 2004). This phenomenon is clearly seen in Lincoln Basin. In the first 15 years of operation, $35 \times 10^{6} \mathrm{~m}^{3}$ was pumped from the basin at an average of $2.13 \times 10^{6} \mathrm{~m}^{3}$ per annum. This corresponded with an increase in salinity and resulted in reduced pumping from the resource. During the subsequent 35 years (1978-2017), the total groundwater extraction from the Lincoln Basin was reduced to $21 \times 10^{6} \mathrm{~m}^{3}$ at an average annual extraction of $0.627 \times 10^{6} \mathrm{~m}^{3}$. The total recharge received over the last 35 years is estimated to be about $56 \times 10^{6} \mathrm{~m}^{3}$ at an annual average of $1.64 \times 10^{6} \mathrm{~m}^{3}$. Despite recharge exceeding the volumes pumped, salinity measurements show no measurable improvement. Future use of the Lincoln Basin as a water supply source is not possible, except as an emergency supply up to $0.412 \times 10^{6} \mathrm{~m}^{3}$, due to the risk of a further increase in salinity. This case history shows that application of even simple methods of analyses and allocation rules, if adopted, would help to prevent seawater intrusion.

\section{Acknowledgments}

This study was funded by the South Australian Water Corporation under the project, "water security planning in the Eyre Peninsula".

\section{References}

Aharmouch, A., \& Larabi, A. (2001). Numerical modelling of saltwater interface upconing in coastal aquifers. First international conference on saltwater intrusion and coastal aquifers monitoring, modelling and management, Essaouria, Morocco, 23-25 April 2001, pp. 1-12.

Alley, M., \& Leake, S. A. (2004). The journey from safe yield to sustainability. Ground Water, 42, 12-16.

Beebe, C. R., Ferguson, G., Gleeson, T., Morgan, L. K., \& Werner, A. D. (2016). Application of an analytical solution as a screening tool for sea water intrusion. Groundwater, 54(5), 709-718.

Bish, S., Gates, G., Gill, J., \& Williams, R. M. (2006). Assessment of sustainable limits for groundwater sources in NSW. 10th Murray-Darling Basin Groundwater Workshop, Murray Darling Basin Commission, Canberra, Australia.

Bobba, A. G. (2002). Numerical modelling of saltwater intrusion due to human activities and sea level change in the Godavari Delta, India. Hydrological Sciences Journal, 47(S1), S67-S80. https://doi.org/10.1080/ 02626660209493023

Carol, E., Kruse, E., \& Mas-Pla, J. (2009). Hydrochemical and isotopical evidence of groundwater salinization processes on the coastal plain of Samborombon Bay, Argentia. Journal of Hydrology, 365(2009), 335-345.

Cheng, A. H. D., \& Ouazar, D. (1999). Chapter 6: Analytical Solutions In J. Bear, H. D. Cheng, S. Sorek, D. Ouzar, \& I. Herrera (Eds.), Seawater Intrusion in Coastal Aquifers-Concepts, Methods and Practices (pp. 163-192). Kluwer Academic Publishers, The Netherlands.

Custodio, E. (1987a). Prediction Methods, Chapter 8. In E. Custodio \& G. A. Bruggeman (Eds.), Groundwater Problems in Coastal Areas, Studies and Reports in Hydrology. United Nations Educational, Scientific and Cultural Organization, Paris, France.

Custodio, E. (1987b). Salt-fresh water interrelationships under natural conditions. Chapter 3. In E. Custodio, \& G. A. Bruggeman (Eds.), Groundwater Problems in Coastal Areas, Studies and Reports in Hydrology. United Nations Educational, Scientific and Cultural Organization, Paris, France.

Dagan, G., \& Bear, J. (1968). Solving the problem of local interface upconing in a coastal aquifer by the method of small perturbation. Journal of Hydraulic Research, 6, 15-44.

Department of Water. (2011). Groundwater risk based allocation planning process, Report No 45. Government of Western Australia. 
Dogan, A., \& Fares, A. (2008). Effects of land-use changes and groundwater pumping on salt water intrusion in coastal watersheds. WIT Transactions on State of the Art in Science and Engineering, 33, https://doi.org/10.2495/978-1-84564-091-0/08

Eriksson, E., \& Khunakasem, V. (1969). Chloride concentration in groundwater, recharge rate and rate of deposition of chloride in the Israel Coastal Plain. Journal of Hydrology, 7, 178-197.

Felisa, G., Ciriello, V., \& Federico, V. D. (2013). Saltwater intrusion in coastal aquifers: A primary case study along the Adriatic coast investigated within a probabilistic framework. Water, 2013(5), 1830-1847. https://doi.org/10.3390/w5041830

Gingerich, S., \& Voss, C. (2002). Three dimensional variable-density flow simulationof a coastal aquifer in southern Oahu, Hawaii, USA. In Boekelman (Ed.), Proceedings SWIM17 Delft 2002 (pp. 93-103). Delft Univ. of Technol., Delft, Netherlands.

Goldman, D., Gilad, D., Ronen, A., \& Melloul, A. (1991). Mapping of seawater intrusion into the coastal aquifer of Israel by time domain electromagnetic method. Geoexploration, 28(2), 153-174.

Healy, R. W., \& Cook, P. G. (2002). Using groundwater levels tostimate recharge. Hydrogeology Journal, 10, 91-109.

Herczeg, A. L., Dogramaci, S. S., \& Leaney, F. W. J. (2001). Origin of dissolved salts in a large, semi-arid groundwater system: Murray Basin, Australia. Marine and Freshwater Research, 52(1), 41-52.

Hutton, J. T. (1976). Chloride in rainwater in relation to distance from the ocean. Search, 7, 207-208.

Huyakorn, P. S., Anderson, P. F., Mercer, J. W., \& White, H. O. (1987). Saltwater intrusion in aquifers: Development and testing of a three-dimensional finite element model. Water Resources Research, 23(2), 293-312.

Kacimov, A. R., \& Obnosov, Y. V. (2000). Analytical solution for a sharp interface problem in sea water intrusion into a coasta aquifer. Proc. R. Soc. Lond. A, 7, 3023-3038.

Kacimov, A. R., Obnosov, Y. V., Sherif, M. M., \& Perret, J. S. (2006). Analytical solution to a sea-water intrusion problem with a fresh water zone tapering to a triple point. Journal of Engineering Mathematics, 54, 197-210. https://doi.org/10.1007/s10665-006-9030-9

Kacimov, A. R., Sherif, M. M., Perret, J. S., \& Al-Mushikhai, A. (2005). Control of sea-water intrusion by salt-water pumping: Coast of Oman. Hydrogeology Journal. https://doi.org/10.1007/s10040-008-0425-8

Kafri, U., \& Goldman, D. (2005). The use of the time domain electromagnetic method to delineate saline groundwater in granular and carbonate aquifers and to evaluate their porosity. Journal of Applied Geophysics, 57, 167-178.

Kalf, F. R. P., \& Wooley, D. R. (2005). Applicability and methodology of determining sustainable yield in groundwater systems. Hydrogeology Journal, 13(1), 295-312. https://doi.org/10.1007/s10040-004-0401-X

Kim, Y., Lee, K., Koh, D., Lee, D., Lee, S., Park, W., Koh, G., \& Woo, N. (2003). Hydrochemical and isotopic evidence of groundwater salinization in a coastal aquifers: a case study in Jeju volacanic island, Korea. Journal of Hydrology, 270, 282-294.

Koussis, A. D., Mazi, K., Riou, F., \& Destouni, G. (2015). A correction for Dupuit-Forchheimer interface flow models of seawater intrusion in unconfined coastal aquifers. Journal of Hydrology. http://dx.doi.org/10. 1016/j.jhydrol.2015.03.047

Mantoglou, A. (2003). Pumping management of coastal aquifers using analytical models of salt water intrusion. Water Resources Research, 39(12). https://doi.org/10.1029/2002WR001891

Morgan, L. K., Werner, A. D., Morris, M. J., \& Teubner, M. D. (2013). Application of a rapid assessment method of SWI: Willunga Basin, South Australia. In C. Wezelhuetter (Ed.), Groundwater in the Coastal Zones of Asia-Pacific (pp. 205-225). Coastal Research Library 7, Springer.

Naderi, M. N. N., Kermani, M. R. H., \& Barani, G-A. (2013). Possibility of groundwater operation in coastal aquifers for prevention of seawater intrusion. Bulletin of Environment, Pharmacology and Life Sciences, 2(11), 30-38.

Painter, J. A. C. (1970). Eyre Peninsula Groundwater Study, Consolidated Report No.2, Summay of available data, Report Book No. 70/151, Department of Mines, South Australia. 
Pool, M., \& Carrera, J. (2011). A correction factor to account for mixing in Ghyben-Herzberg and critical pumping rate approximation of seawater intrusion in coastal aquifers. Water Resources Research, 47, W05506. http://dx.doi.org/10.1029/2010WR010256

SALTRANS. (2004). Methods for assessing salt intrusion and transport in heterogeneous and fractured aquifers. Deliverable 14: Basic principles and concepts for understanding and managing sea water intrusion in coastal aquifers, European Commission Programme: Energy, Environment and Sustainable Development, Contract No. EVK1-2000-00062.

Sanford, W. E., \& Pope, J. P. (2010). Current challenges using models to forecast sea water intrusion: lessons from the Eastern Shore of Virginia, USA. Hydrogeology Journal, 18(1), 73-93.

Selby, J. (1972). Eyre Peninsula Groundwater Survey, Lincoln Basin (Hundreds of Lincoln, Sleaford and Flinders), Pump test results on boreholes $O, P$ and $Q$. Report Book No. 72/110. Department of Mines, South Australia.

Shepherd, R. G. (1959). Lincoln basin investigations, Preliminary Report. Department of Mines, South Australia, Rept. BK49/26, D.M. 2300/57.

Shepherd, R. G. (1962). Underground water investigations, Southern Eyre Peninsula. Undergroundwater Conference of Australia 1962 Symposium, Adelaide. Department of Mines, South Australia, Rept. BK54/154.

Sibenaler, X. P. (1975). Eyre Peninsula Groundwater Survey, Lincoln Basin Pump Test Results Borehole R. Department of Mines South Australia, Report Book No. 75/112.

Somaratne, N. (2014). Characteristics of point recharge in karst aquifers. Water, 2014(6), 2782-2807. http://dx.doi.org/10.3390/w6092782

Somaratne, N., \& Ashman, G. (2018). Saline intrusion into the Lincoln Basin: Legacy issues and challenges to water security. South Australian Water Corporation, Internal Report, ResearchGate.

Strack, O. D. L. (1976). A single-potential solution for regional interface problems in coastal aquifers. WaterResources Research, 12(6), 1165-1174.

Tremblay, J. J., D’cruz, A., \& Auger, H. (1973). Saltwater intrusion in the Summerside area, P.E.I. Groundwater, $11,42-49$.

YSI Incorporated. (2014). Environmental Monitoring Systems Operations Manual. Retrieved September 3, 2014, from http://wenku.baidu.com/view/d785b92058fb770bf78a55ca.html

Zulfic, H., \& Somaratne, N. (2012). Lincoln Basin Town Water Supply-Review. SA Water Internal Report (unpublished).

\section{Copyrights}

Copyright for this article is retained by the author(s), with first publication rights granted to the journal.

This is an open-access article distributed under the terms and conditions of the Creative Commons Attribution license (http://creativecommons.org/licenses/by/4.0/). 